\title{
Superior mesenteric artery syndrome as a cause of acute pancreatitis
}

\author{
Shinichi Kojima, ${ }^{1}$ Kei Suzuki, ${ }^{1,2}$ Naoyuki Katayama, ${ }^{2}$ Hiroshi Imai $^{1}$
}

\begin{abstract}
${ }^{1}$ Emergency and Critical Care Center, Mie University Hospital, Tsu, Mie, Japan ${ }^{2}$ Department of Hematology and Oncology, Mie University Graduate School of Medicine, Tsu, Mie, Japan
\end{abstract}

\section{Correspondence to}

Dr Kei Suzuki,

keis@clin.medic.mie-u.ac.jp

Accepted 5 September 2016

\section{DESCRIPTION}

A 76-year-old man with no history of alcohol abuse was brought to the emergency department with disturbance of consciousness after repeated vomiting. On arrival, he was drowsy and in shock with a systolic blood pressure of $\sim 60 \mathrm{~mm} \mathrm{Hg}$ and heart rate of $150 \mathrm{bpm}$. On physical examination, he was cachectic (body mass index, $15.6 \mathrm{~kg} / \mathrm{m}^{2}$ ) with a distended abdomen. Plain CT showed gastric and duodenal distension with abrupt narrowing at the third portion of the duodenum, with the superior mesenteric artery (SMA) crossing anterior to the transition point (figure 1A). Laboratory examination revealed elevated serum amylase of $4132 \mathrm{U} / \mathrm{L}$ and $\mathrm{C}$ reactive protein of $10.74 \mathrm{mg} / \mathrm{dL}$, with moderately elevated liver enzymes. Contrast CT performed after gastric decompression via nasogastric tube demonstrated swelling of the pancreatic head and surrounding fluid collection (figure 1B). Ultrasonography did not show biliary stone. Reconstructed CT revealed a reduced aortomesenteric angle of $18^{\circ}$ (figure 2).

Although idiopathic case could not be denied, the patient was diagnosed with acute pancreatitis with hypovolemic shock resulting from increased intraduodenal pressure due to SMA syndrome (SMAS) and gas bloat. ${ }^{1} \mathrm{He}$ was treated conservatively for acute pancreatitis with nasogastric drainage for SMAS, and recovered from shock in 24 hours. Enteral alimentation resulted in gradual improvement of his nutritional status, and he was transferred to another hospital for subsequent management after 6 weeks, without recurrence of acute pancreatitis.

The association of SMAS with acute pancreatitis is rarely reported. ${ }^{1-3}$ Secondary occlusive postpapillary syndrome due to SMAS may produce a

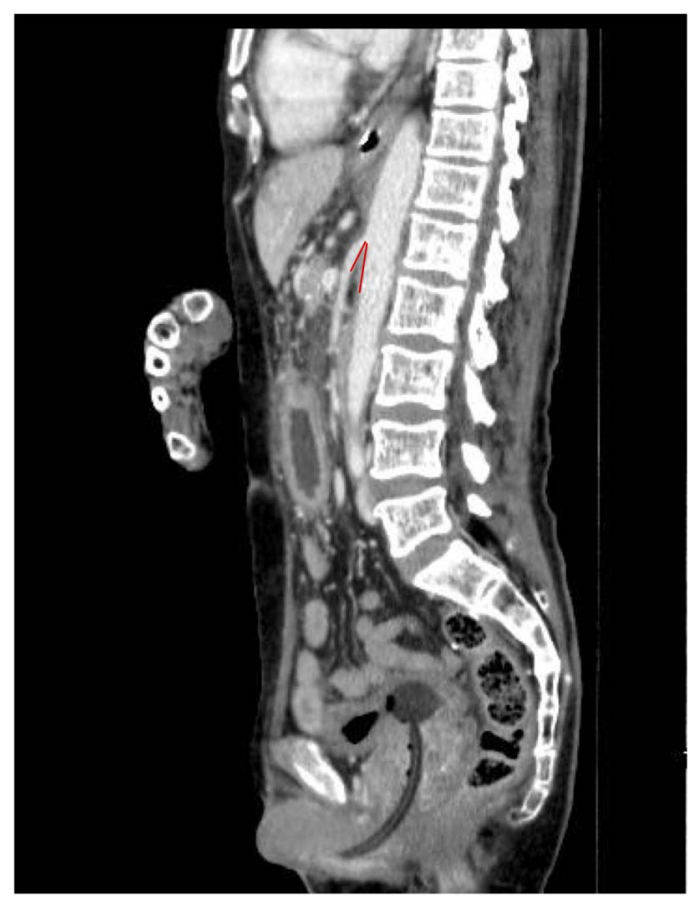

Figure 2 Sagittal multiplanar reconstruction contrast-enhanced CT showing the SMA arising from the aorta, forming a narrow aortomesenteric angle (red lines) of $18^{\circ}$ (normal, $45-60^{\circ}$ ). SMA, superior mesenteric artery.

retrograde reflux of bile into the pancreatic duct, which activates the inflammatory phenomena responsible for pancreatitis. ${ }^{2}$ It is important to consider SMAS as a cause of pancreatitis, especially in patients with cachexia with gastric distension accompanying acute pancreatitis of unknown aetiology.

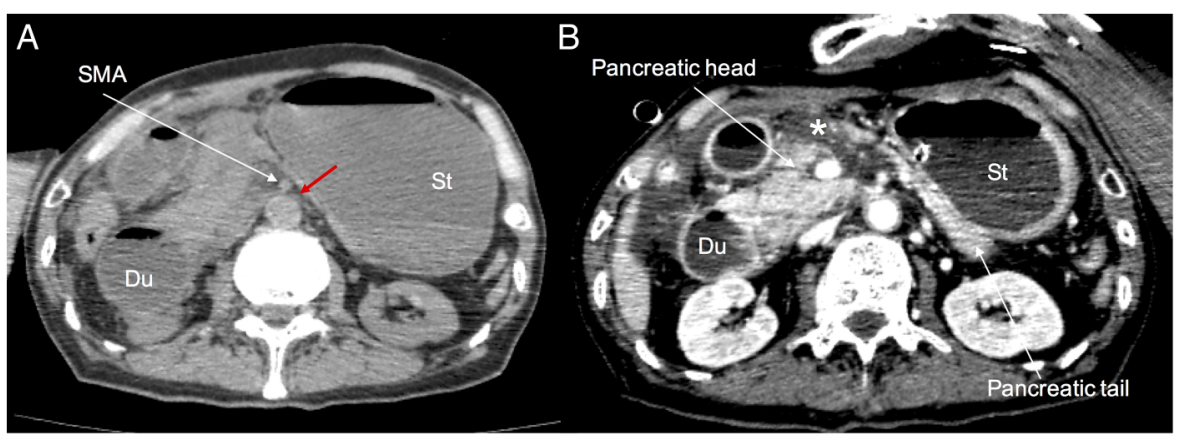

To cite: Kojima S, Suzuki K, Katayama N, et al. BMJ Case Rep Published online: [please include Day Month Year] doi:10.1136/bcr-2016217073
Figure 1 (A) CT axial section demonstrating compression of the third part of the duodenum between the SMA and abdominal aorta (red arrow), with proximal duodenal and gastric dilation. SMA, superior mesenteric artery; Du, duodenum; St, stomach. (B) Contrast-enhanced CT showing swelling of the pancreatic head with poor contrast-enhanced area $\left(^{*}\right)$ and surrounding fluid collection extending to the inferior area of the right kidney, suggesting acute pancreatitis. Stones were not detected in the gall bladder or common bile duct. Du, duodenum; St, stomach. 


\section{Learning points}

- A history suggestive of upper gastrointestinal obstruction, such as epigastric pain and repeated vomiting, in a patient with cachexia should raise the clinical suspicion of superior mesenteric artery syndrome (SMAS).

- SAMS is diagnosed primarily based on CT findings, include a dilated stomach and proximal duodenum and reduced aortomesenteric angle on sagittal multiplanar reconstruction CT.

SMAS occasionally accompanies acute pancreatitis.

Acknowledgements The authors thank all the colleagues of the emergency and critical care centre, Mie University Hospital (T. Hiramoto, Y. Iwashita, B. Hara, E. Kawamoto, K. Yokoyama, A. Yamamoto, Y. Omori, K. Ishikura, M. Fujioka,

T. Takeda and K. Maruyama) for their cooperation.
Contributors SK was the attending physician in the case. SK, KS and HI were involved in the case. KS drafted the manuscript and NK reviewed and supervised it. All the authors approved the final version.

Funding This study was funded in part by a grant under the category, 'Mie University Hospital Seed Grant Program 2015', from Mie University Hospital (to HI and KS) and 'JSPS KAKENHI Grant Number 16K20384' (to KS).

Competing interests None declared.

Patient consent Obtained.

Provenance and peer review Not commissioned; externally peer reviewed.

\section{REFERENCES}

1 Inoue $\mathrm{M}$, Uchida $\mathrm{K}$, Otake $\mathrm{K}$, et al. Development of acute pancreatitis after Nissen fundoplication. Pediatr Int 2015;57:e48-9.

2 Sihuay-Diburga DJ, Accarino-Garaventa A, Vilaseca-Montplet J, et al. Acute pancreatitis and superior mesenteric artery syndrome. Rev Esp Enferm Dig 2013;105:626-8.

3 Gweek K, Teh A, Haung C. Acute superior mesenteric artery syndrome and pancreatitis in anorexia nervosa. Australas Psychiatry 2010;18:523-6.

Copyright 2016 BMJ Publishing Group. All rights reserved. For permission to reuse any of this content visit http://group.bmj.com/group/rights-licensing/permissions.

BMJ Case Report Fellows may re-use this article for personal use and teaching without any further permission.

Become a Fellow of BMJ Case Reports today and you can:

- Submit as many cases as you like

- Enjoy fast sympathetic peer review and rapid publication of accepted articles

- Access all the published articles

- Re-use any of the published material for personal use and teaching without further permission

For information on Institutional Fellowships contact consortiasales@bmjgroup.com

Visit casereports.bmj.com for more articles like this and to become a Fellow 